\title{
Low Cost Microwave Plasma Generation System - A Power Analysis study
}

\author{
Smitha I.S \\ Dept of EIE \\ FISAT, Kerala
}

\author{
Sreejith K.R \\ Dept of EIE \\ FISAT, Kerala
}

\author{
Anish Mathew K \\ Dept of EIE \\ FISAT, Kerala
}

\author{
K.Rajeevkumar \\ Dept of Instrumentation \\ CUSAT, Kerala
}

\begin{abstract}
In the study of thin film preparation using a low cost microwave induced plasma method, we have carried out calorimetric power analysis in a microwave oven with different loads. The calorimetric calibration was done with various heating loads like coconut oil, engine oil, fruit juice and water. The power consumption of water was higher when compared to other loads. The results show the comparison of thermal properties and heating characteristics of coconut oil ,engine oil, fruit juice and water when they are exposed to microwave radiation.
\end{abstract}

\section{Keywords}

Microwave plasma, calorimetric method, power, Microwave oven.

\section{INTRODUCTION}

Microwave plasma deposition system has several advantages when compared to other deposition systems [1]. Nano structures of various materials like $\mathrm{ZnO}, \mathrm{SnO}_{2}$ etc can be deposited using a low cost microwave induced plasma deposition system developed from a domestic microwave oven. A quartz tube inside the chamber of the oven acts as the applicator which when exposed to microwaves generates a plasma within the tube. Plasma is formed by the interaction of microwaves with the gases at appropriate low pressure inside the quartz tube. Pressure inside the quartz tube can be adjusted using a vacuum system. Vacuum system consists of a Rotary vacuum pump, vacuum lines, valves and Pirani gauge. For microwave power calibration inside the chamber, we adopted calorimetric calibration method with various types of heating loads such as coconut oil, engine oil, fruit juice and water. We followed the International Standards set by IEC 705(1988) [2]. This standard gives a relation between microwave power applied and increase of temperature in loads, as

$$
P=\frac{\Delta T \times V \times C \times \rho}{t}
$$

where,
$\mathrm{C}$ : Specific heat capacity in $\mathrm{kJ} / \mathrm{kg} . \mathrm{K}$

$\rho:$ Density of the fluid in $\mathrm{kg} / \mathrm{m}^{3}$

$\mathrm{t}$ : Time of heating in seconds.

$\Delta T$ : Mean temperature rise in Kelvin

\section{EXPERIMENT DETAILS}

The equipments and materials used are:

- Microwave oven: - Whirlpool Magic cook 20S, $2.45 \mathrm{GHz}$ microwave oven with supply voltage $230 \mathrm{~V} / 50 \mathrm{~Hz}$, and rated input $1100 \mathrm{~W}$. Output power consumption $700 \mathrm{~W}$, 20L cavity volume, Cavity dimensions, 196x292x295 mm.

- Dimmer stat: - Supply voltage variation can affect the magnetron output power. To prevent such fluctuation we need to use dimmer stat which fixes the supply voltage at rated level.

- Calorimetric calibrations were carried out using equipments such as thermometers, borosil glass beaker and stop watch.

- The containers used for the experiment are borosil glassware. Weight of the glass beakers used is as follows. Small beaker $67.834 \mathrm{~g}(140 \mathrm{ml})$, Medium Size beaker $105.563 \mathrm{~g} \quad(200 \mathrm{ml})$, Large sized beaker 163.444g (400ml). Plastic containers (polypropylene $\mathrm{PP})$ round and angular shape.

- Engine oil (HP racer 2T), virgin coconut oil Rasna fruit juice concentrate and water.

Fig.1 shows the block schematic of the plasma deposition unit. The domestic microwave oven was set to act as a low cost plasma deposition unit by inserting a cylindrical quartz tube through the heating cavity of the microwave oven [9].

\footnotetext{
P: Microwave power consumption in watts.

$\mathrm{V}$ : Volume of load within the cavity in $\mathrm{mL}$
} 


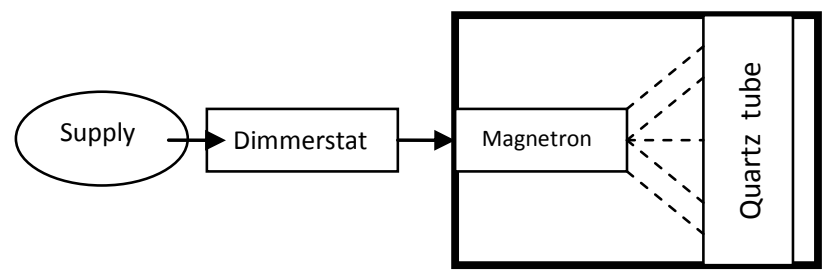

Fig.1 Block schematic of the plasma deposition unit.

\section{A. Procedures for calorimetric power analysis on heating loads.}

- Take $\mathrm{V} \mathrm{ml}$ of the heating load in a borosil glass beaker. Stir the beaker contents for 20 seconds and record the initial temperature $\left(\mathrm{T}_{1}\right)$ using thermometer in degree Celsius scale [3].

- Dimmerstat is varied for obtaining the rated voltage of the oven.

- $\quad$ Place the container at the centre position of the oven.

- Switch on the oven, and heat the load for time' $t$ ' seconds.

- After ' $t$ ' seconds oven is switched off and the beaker is taken out carefully.

- Stir the contents for 20 seconds. And find the final temperature $\left(\mathrm{T}_{2}\right)$.

The output power is determined by the equation [3]

$$
P=\frac{\left(M_{f} C_{p-f}+M_{g} C_{p-g}\right) \Delta T}{t}
$$

where, $M_{f}$ and $M_{g}$ are the mass of the fluid and the beaker respectively. $\mathrm{C}_{\mathrm{p}-\mathrm{f}}$ and $\mathrm{C}_{\mathrm{p}-\mathrm{g}}$ are the specific heats of the fluid and beaker respectively. $\Delta \mathrm{T}$ is the rise in temperature and $\mathrm{t}$ is the time in seconds.

\section{RESULTS AND DISCUSSION}

The average power absorbed for various values of load parameters were calculated. Magnetron input voltage was kept at the rated voltage of $230 \mathrm{~V} 50 \mathrm{~Hz}$ by the dimmer stat. Power absorbed was calculated using the IEC 705 formula.

\section{A. HEATING LOAD 1: Power absorbed with heating load as Coconut oil.}

Weight of $100 \mathrm{ml}$ of coconut oil is $88.766 \mathrm{~g}$. Specific Heat of coconut oil is $1.67 \mathrm{KJ} / \mathrm{kgK}$.

Table.1 Power analysis of $50 \mathrm{ml}$ Coconut oil as heating load with heating time of 60 seconds.

\begin{tabular}{|c|c|c|c|c|}
\hline \multicolumn{5}{|c|}{$\mathrm{m}_{\mathrm{f}}=44.38 \mathrm{~g} \mathrm{c}_{\mathrm{f}}=1.67 \mathrm{KJ} / \mathrm{KgK}$} \\
$\mathrm{m}_{\mathrm{g}}=67.834 \mathrm{~g} \quad \mathrm{c}_{\mathrm{g}}=0.74 \mathrm{~J} / \mathrm{KgK}$. \\
\hline $\begin{array}{c}\text { Sl. } \\
\text { No }\end{array}$ & $\begin{array}{c}\text { Initial } \\
\text { Temp(C) }\end{array}$ & $\begin{array}{c}\text { Final } \\
\text { Temp(C) }\end{array}$ & $\Delta \mathrm{T}$ & Power-W \\
\hline 1 & 29 & 125 & 96 & 198.899 \\
\hline 2 & 29 & 123 & 94 & 194.755 \\
\hline 3 & 29 & 124 & 95 & 196.827 \\
\hline
\end{tabular}

Table.2 Power analysis of $100 \mathrm{ml}$ Coconut oil as heating load with heating time of 120 seconds.

\begin{tabular}{|c|c|c|c|c|}
\hline \multicolumn{4}{|c|}{$\mathrm{m}_{\mathrm{f}}=88.766 \mathrm{~g} \mathrm{c}_{\mathrm{f}}=1.67 \mathrm{KJ} / \mathrm{KgK}$} \\
$\mathrm{m}_{\mathrm{g}}=67.834 \mathrm{~g}$ & $\mathrm{c}_{\mathrm{g}}=0.74 \mathrm{KJ} / \mathrm{KgK}$ \\
\hline $\begin{array}{c}\text { Sl. } \\
\text { No }\end{array}$ & $\begin{array}{c}\text { Initial } \\
\text { Temp(C) }\end{array}$ & $\begin{array}{c}\text { Final } \\
\text { Temp(C) }\end{array}$ & $\Delta \mathrm{T}$ & Power-W \\
\hline 1 & 28 & 185 & 157 & 259.621 \\
\hline 2 & 28 & 190 & 162 & 267.889 \\
\hline 3 & 28 & 187 & 159 & 262.928 \\
\hline
\end{tabular}

Table.3 Power analysis of $150 \mathrm{ml}$ Coconut oil as heating load with heating time of 180 seconds.

\begin{tabular}{|l|l|l|l|l|}
\hline \multicolumn{3}{|l|}{$\mathrm{m}_{\mathrm{f}}=133.149 \mathrm{~g}$} & \multicolumn{2}{l|}{$\mathrm{c}_{\mathrm{f}}=1.67 \mathrm{KJ} / \mathrm{KgK}$} \\
$\mathrm{m}_{\mathrm{g}}=105.563 \mathrm{~g}$ & \multicolumn{2}{l|}{$\mathrm{c}_{\mathrm{g}}=0.74 \mathrm{KJ} / \mathrm{KgK}$} \\
\hline $\begin{array}{l}\text { Sl. } \\
\text { No }\end{array}$ & $\begin{array}{l}\text { Initial } \\
\text { Temp(C) }\end{array}$ & $\begin{array}{l}\text { Final } \\
\text { Temp(C) }\end{array}$ & $\Delta \mathrm{T}$ & Power-W \\
\hline 1 & 27 & 210 & 183 & 305.483 \\
\hline 2 & 28 & 208 & 180 & 300.475 \\
\hline 3 & 27 & 210 & 183 & 305.483 \\
\hline
\end{tabular}


Table 4: Final average values of analysis of coconut oil.

\begin{tabular}{|l|l|}
\hline Time & Power In watts \\
\hline 60 seconds & 196.827 \\
\hline 120 seconds & 263.479 \\
\hline 180 seconds & 303.814 \\
\hline
\end{tabular}

Fig.2 shows the average power analysis graph for coconut oil as heating load with variable quantity and time.

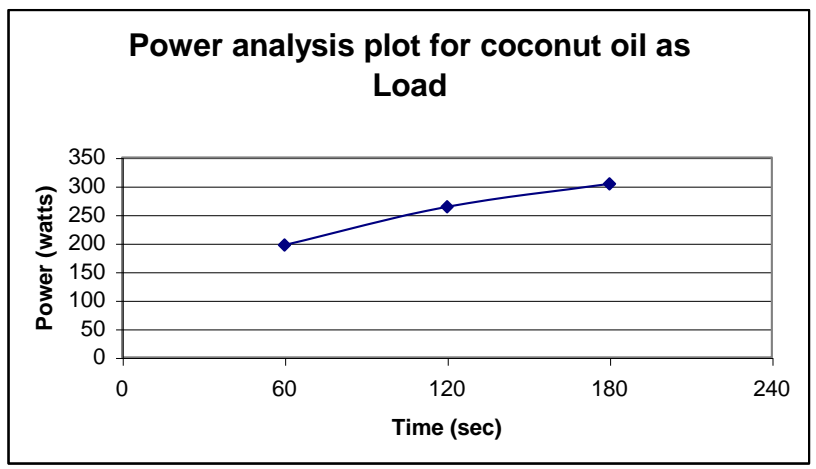

Fig.2 Average power analysis for coconut oil.

Vegetable oils are perceived to be alternatives to mineral oils as base oils for industrial lubricants due to growing environmental concerns. Vegetable oil based lubricants offer significant environmental benefits with respect to resource renewability, low toxicity, and provide satisfactory performance in a wide array of applications [4],[5]. Vegetable oils in general have excellent properties such as high viscosity index, high lubricity, high flash point, and low evaporative loss with regard to their use as base oils for lubricants. On the negative side, they are known to possess low thermal, oxidative and hydrolytic stabilities and poor low temperature characteristics. Vegetable oils are also found to be temperature sensitive in the case of tribological properties especially at high temperatures. Some of the important base oil properties of industrial lubricants are viscometric, physico-chemical, tribological, oxidative, thermal, hydrolytic, corrosion and low temperature properties.[4,5,6]. The poor cold flow properties of vegetable oils can be attributed to their unique molecular structure, namely, triacylglycerol structure [5]. Vegetable oils have a tendency to form macro crystalline structures at low temperature through uniform stacking of 'bend' triacylglycerol backbone. Such macro crystals restrict the easy flow of the system due to loss of kinetic energy of individual molecules during self stacking. The predominantly saturated fatty acid content of certain tropical oils like coconut oil compounds the problem further. This is attributed to close packing of the saturated fatty acid chains in triacylglycerols. During heating process these chain distance increases, so the power absorbed increases.

\section{B. HEATING LOAD 2: Power absorbed with heating load as Engine oil.}

Weight of $100 \mathrm{ml}$ of Engine oil is $91.3 \mathrm{gm}$. Specific heat capacity of Engine oil is $2.09 \mathrm{KJ} / \mathrm{kgK}$.

Table.5 Power analysis of 50ml Engine oil as heating load with heating time of 60 seconds.

\begin{tabular}{|c|c|c|c|c|}
\hline \multicolumn{2}{|c|}{$\begin{array}{l}\mathrm{m}_{\mathrm{f}}=45.65 \mathrm{~g} \\
\mathrm{~m}_{\mathrm{g}}=67.834 \mathrm{~g}\end{array}$} & \multicolumn{3}{|c|}{$\begin{array}{l}\mathrm{c}_{\mathrm{f}}=2.09 \mathrm{~K} \mathrm{~J} / \mathrm{KgK} \\
\mathrm{c}_{\mathrm{g}}=0.74 \mathrm{KJ} / \mathrm{KgK}\end{array}$} \\
\hline $\begin{array}{l}\text { Sl. } \\
\text { No }\end{array}$ & $\begin{array}{l}\text { Initial } \\
\text { Temp }(C)\end{array}$ & $\begin{array}{l}\text { Final } \\
\text { Temp }(C)\end{array}$ & $\Delta \mathrm{T}$ & Power-W \\
\hline 1 & 29 & 38 & 9 & 21.841 \\
\hline 2 & 29 & 39 & 10 & 24.268 \\
\hline 3 & 28 & 38 & 10 & 24.268 \\
\hline & & \multicolumn{2}{|c|}{ Avg Power } & 23.459 \\
\hline
\end{tabular}

Table.6 Power analysis of $100 \mathrm{ml}$ Engine oil as heating load with heating time of 120 seconds.

\begin{tabular}{|l|l|l|l|l|}
\hline \multicolumn{2}{|l|}{$\mathrm{m}_{\mathrm{f}}=91.3 \mathrm{~g} \quad \mathrm{c}_{\mathrm{f}}=2.09 \mathrm{KJ} / \mathrm{KgK}$} \\
$\mathrm{m}_{\mathrm{g}}=67.834 \mathrm{~g} \quad \mathrm{c}_{\mathrm{g}}=0.74 \mathrm{KJ} / \mathrm{KgK}$ \\
\hline $\begin{array}{l}\text { Sl. } \\
\text { No }\end{array}$ & $\begin{array}{l}\text { Initial } \\
\text { Temp(C) }\end{array}$ & $\begin{array}{l}\text { Final } \\
\text { Temp(C) }\end{array}$ & $\Delta \mathrm{T}$ & Power-W \\
\hline 1 & 29 & 48 & 20 & 40.169 \\
\hline 2 & 28 & 49 & 21 & 42.177 \\
\hline 3 & 28 & 49 & 23 & 46.194 \\
\hline
\end{tabular}

Table.7 Power analysis of 150ml Engine oil as heating load with heating time of 180 seconds. 


\begin{tabular}{|c|c|c|c|c|}
\hline \multicolumn{2}{|c|}{$\begin{array}{l}\mathrm{m}_{\mathrm{f}}=136.95 \mathrm{~g} \\
\mathrm{~m}_{\mathrm{g}}=105.563 \mathrm{~g}\end{array}$} & \multicolumn{3}{|c|}{$\begin{array}{l}\mathrm{c}_{\mathrm{f}}=2.09 \mathrm{KJ} / \mathrm{KgK} \\
\mathrm{c}_{\mathrm{g}}=0.74 \mathrm{KJ} / \mathrm{KgK}\end{array}$} \\
\hline $\begin{array}{l}\text { Sl. } \\
\text { No }\end{array}$ & $\begin{array}{l}\text { Initial } \\
\text { Temp(C) }\end{array}$ & $\begin{array}{l}\text { Final } \\
\text { Temp(C) }\end{array}$ & $\Delta \mathrm{T}$ & $\begin{array}{l}\text { Power- } \\
\mathrm{W}\end{array}$ \\
\hline 1 & 29 & 69 & 40 & 80.965 \\
\hline 2 & 28 & 68 & 40 & 80.965 \\
\hline 3 & 29 & 67 & 38 & 76.917 \\
\hline & & \multicolumn{2}{|c|}{ Avg Power } & \\
\hline
\end{tabular}

Table.8 Final average values of analysis of Engine oil.

\begin{tabular}{|l|l|}
\hline Time & Power in watts \\
\hline 60 seconds & 23.459 \\
\hline 120 seconds & 48.847 \\
\hline 180 seconds & 79.616 \\
\hline
\end{tabular}

Fig.3 shows the average power analysis graph for Engine oil as heating load with variable quantity and time.

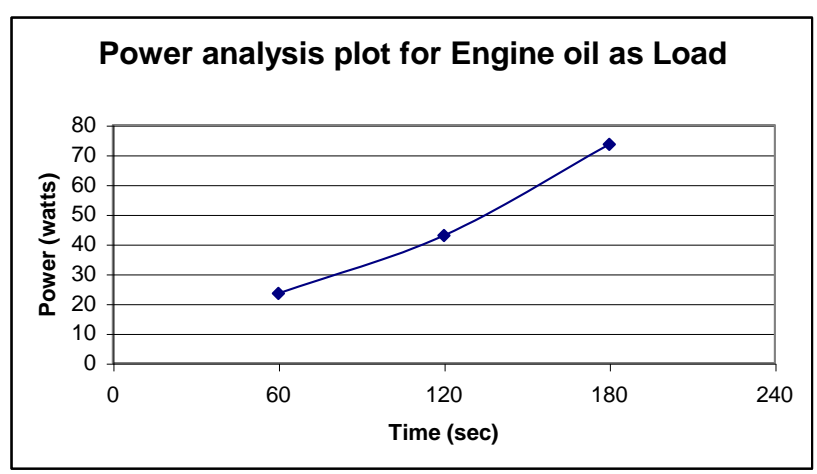

Fig.3 Average power analysis for Engine oil.

Most motor oils are made from a heavier, thicker petroleum hydrocarbon base stock derived from crude oil, with additives to improve certain properties. One of the most important properties of motor oil in maintaining a lubricating film between moving parts is its viscosity [7]. The viscosity of a liquid can be thought of as its "thickness" or a measure of its resistance to flow. The viscosity must be high enough to maintain a lubricating film, but low enough that the oil can flow around the engine parts under all conditions. The viscosity index is a measure of how much the oil's viscosity changes as temperature changes. A higher viscosity index indicates the viscosity changes less with temperature than a lower viscosity index. Depending on the performance of the oil, engine oil is classified into two-single grade oil and multi grade oil. Single grade engine oil is used in low capacity engine. Single step engine oil doesn't have viscosity modifiers. As a result of the polymeric additives in the multi grade engine oil, the heat absorption changes. The rise in power absorption of the engine oil as heating load is lower when compared to other heating loads on account of the additives which are added (Viscosity Modifiers).

\section{Heating Load 3: Power absorbed with heating load as fruit juice.}

Weight of $100 \mathrm{ml}$ of fruit juice is $100 \mathrm{~g}$. Specific heat capcity of fruit juice $3.93 \mathrm{KJ} / \mathrm{KgK}$.

Table.9 Power analysis of fruit juice concentration of $0.2 \mathrm{~g} / \mathrm{ml}$ with heating time of 45 seconds.

\begin{tabular}{|c|c|c|c|c|}
\hline \multicolumn{2}{|c|}{$\begin{aligned} \mathrm{m}_{\mathrm{f}} & =0.06 \mathrm{Kg} \\
\mathrm{m}_{\mathrm{g}} & =0.067 \mathrm{Kg}\end{aligned}$} & \multicolumn{2}{|c|}{$\begin{array}{c}\mathrm{c}_{\mathrm{f}}=3.93 \mathrm{KJ} / \mathrm{KgK} \\
\mathrm{c}_{\mathrm{g}}=0.74 \mathrm{KJ} / \mathrm{KgK}\end{array}$} & \multirow[b]{2}{*}{ Power-W } \\
\hline $\begin{array}{l}\text { Sl. } \\
\text { No }\end{array}$ & $\begin{array}{l}\text { Initial } \\
\text { Temp }(C)\end{array}$ & $\begin{array}{l}\text { Final } \\
\text { Temp(C) }\end{array}$ & $\Delta \mathrm{T}$ & \\
\hline 1 & 32 & 94 & 55 & 288.261 \\
\hline 2 & 33 & 95 & 54 & 283.02 \\
\hline 3 & 28 & 94 & 54 & 283.02 \\
\hline \multicolumn{4}{|c|}{ Avg Power } & 284.767 \\
\hline
\end{tabular}

Table.10 Power analysis of fruit juice concentration of $0.4 \mathrm{~g} / \mathrm{ml}$ with heating time of 45 seconds.

\begin{tabular}{|l|l|l|l|l|}
\hline \multicolumn{3}{|l|}{$\mathrm{m}_{\mathrm{f}}=0.07 \mathrm{Kg}$} & $\mathrm{c}_{\mathrm{f}}=3.930 \mathrm{KJ} / \mathrm{KgK}$ \\
$\mathrm{m}_{\mathrm{g}}=0.067 \mathrm{Kg}$ & \multicolumn{2}{l|}{$\mathrm{c}_{\mathrm{g}}=0.74 \mathrm{KJ} / \mathrm{KgK}$} \\
\hline $\begin{array}{l}\text { Sl. } \\
\text { No }\end{array}$ & $\begin{array}{l}\text { Initial } \\
\text { Temp(C) }\end{array}$ & $\begin{array}{l}\text { Final } \\
\text { Temp(C) }\end{array}$ & $\Delta \mathrm{T}$ & Power-W \\
\hline 1 & 33 & 88 & 66 & 403.554 \\
\hline 2 & 32 & 90 & 67 & 409.668 \\
\hline 3 & 33 & 91 & 66 & 403.554 \\
\cline { 3 - 5 } & & Avg Power & 405.592 \\
\cline { 3 - 5 } & &
\end{tabular}

Table.11 Power analysis of fruit juice concentration of $0.6 \mathrm{~g} / \mathrm{ml}$ with heating time of 45 seconds. 


\begin{tabular}{|l|l|l|l|l|}
\hline \multicolumn{5}{|l|}{$\mathrm{m}_{\mathrm{f}}=0.08 \mathrm{Kg} \mathrm{c}_{\mathrm{f}}=3.930 \mathrm{KJ} / \mathrm{KgK}$} \\
$\mathrm{m}_{\mathrm{g}}=0.067 \mathrm{Kg}$ & \multicolumn{2}{l|}{$\mathrm{c}_{\mathrm{g}}=0.74 \mathrm{KJ} / \mathrm{KgK}$} \\
\hline $\begin{array}{l}\text { Sl. } \\
\text { No }\end{array}$ & $\begin{array}{l}\text { Initial } \\
\text { Temp(C) }\end{array}$ & $\begin{array}{l}\text { Final } \\
\text { Temp(C) }\end{array}$ & $\Delta \mathrm{T}$ & Power-W \\
\hline 1 & 29 & 95 & 69 & 482.157 \\
\hline 2 & 28 & 96 & 70 & 489.145 \\
\hline 3 & 29 & 96 & 70 & 489.145 \\
\hline
\end{tabular}

Table.12 Final average values of analysis of Fruit Juice.

\begin{tabular}{|l|l|}
\hline Concentration & Power In watts \\
\hline $0.2 \mathrm{~g} / \mathrm{ml}$ & 284.767 \\
\hline $0.4 \mathrm{~g} / \mathrm{ml}$ & 405.592 \\
\hline $0.6 \mathrm{~g} / \mathrm{ml}$ & 486.816 \\
\hline
\end{tabular}

Fig.4 shows the average power absorption characteristics of fruit juice with varying concentration.

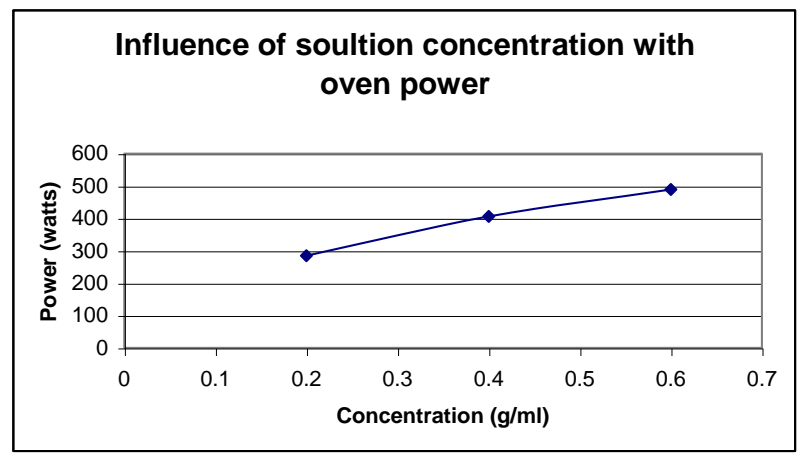

Fig.4 Average power analysis for fruit juice

The susceptibility of a load to heating in a microwave oven depends on many factors probably connected with both the load parameter and the oven characteristics. The value of the microwave power absorbed in the unit volume of heated load $\left(\mathrm{P}_{\mathrm{v}}\right)$ is described theoretically according to BUFFLER by equation below [2].

$P_{v}=2 \times \pi \times f \times \varepsilon_{0} \varepsilon "|E|^{2}$
$\mathrm{P}_{\mathrm{v}}$ - power absorbed in the unit volume of load $\left(\mathrm{W} / \mathrm{m}^{3}\right)$

f- Microwave frequency

$\varepsilon_{0}-$ permittivity of free space.

$\varepsilon "$ - dielectric loss factor of the load.

E- Strength of the electric field inside of the load (V/m).

Since the microwave frequency $(2450 \mathrm{MHz})$ and permittivity of free space $\left(10^{-9} / 36 \pi \mathrm{F} / \mathrm{m}\right)$, the remaining parameters in the equation are related both to the load and to the oven(E).

The variation of the solution power absorption is in line with the expectation of the BUFFLER's equation. The change in concentration changes the dielectric properties of the solution. The change in dielectric influences the heating characteristics [8].

\section{Heating Load 4: Power absorbed with heating load as water.}

Different quantity of water was tested for heating time of 120 seconds. The specific heat capacity of water is $4.2 \mathrm{~kJ} / \mathrm{kg}$.K.

Table.13 Power analysis of $2 \mathrm{~L}$ water heating time of 120 seconds.

\begin{tabular}{|l|l|l|l|}
\hline $\begin{array}{l}\text { Sl } \\
\text { No }\end{array}$ & Initial Temp & Final Temp & Power-W \\
\hline 1 & 27.5 & 35.5 & 558.266 \\
\hline 2 & 27.5 & 35 & 523.375 \\
\hline 3 & 27.5 & 36 & 593.1583 \\
\hline & & Avg power & 558.27 \\
\cline { 3 - 4 } & & & \\
\cline { 3 - 4 } & & &
\end{tabular}

Table.14 Power analysis of $1.5 \mathrm{~L}$ water heating time of 120 seconds.

\begin{tabular}{|l|l|l|l|}
\hline $\begin{array}{l}\text { Sl } \\
\text { No }\end{array}$ & Initial Temp & Final Temp & Power-W \\
\hline 1 & 27.5 & 37.5 & 523.375 \\
\hline 2 & 27.5 & 38 & 549.543 \\
\hline 3 & 27.5 & 37 & 497.2065 \\
& & Avg power & 523.375 \\
\cline { 3 - 4 } & & & \\
\cline { 3 - 4 } & & &
\end{tabular}

Table.15 Power analysis of 1L water heating time of 120 seconds. 


\begin{tabular}{|l|l|l|l|}
\hline S1 No & Initial Temp & Final temp & Power W \\
\hline 1 & 27.5 & 42 & 505.921 \\
\hline 2 & 27.5 & 42 & 505.921 \\
\hline 3 & 27.5 & 42.5 & 523.375 \\
& & Avg Power & 511.744 \\
\cline { 3 - 4 } & & & \\
\cline { 3 - 4 } & &
\end{tabular}

Table.16 Power analysis of $0.75 \mathrm{~L}$ water heating time of 120 seconds.

\begin{tabular}{|l|l|l|l|}
\hline Sl no & Initial Temp & Final Temp & Power W \\
\hline 1 & 27.5 & 45 & 457.953 \\
\hline 2 & 27.5 & 45 & 457.953 \\
\hline 3 & 27.5 & 45 & 457.953 \\
\hline \multirow{2}{*}{} & & Avg power & 457.953 \\
\cline { 3 - 4 } & & & \\
\cline { 3 - 4 } & &
\end{tabular}

Table 17. Final average chart for power analysis with water as the heating load.

\begin{tabular}{|l|l|l|}
\hline Sl no & Volume ml & Power $-\mathrm{w}$ \\
\hline 1 & 750 & 457.953 \\
\hline 2 & 1000 & 511.744 \\
\hline 3 & 1500 & 523.375 \\
\hline 4 & 2000 & 558.266 \\
\hline
\end{tabular}

Fig.5 shows the Power Vs Volume plot characteristics with water as heating load.

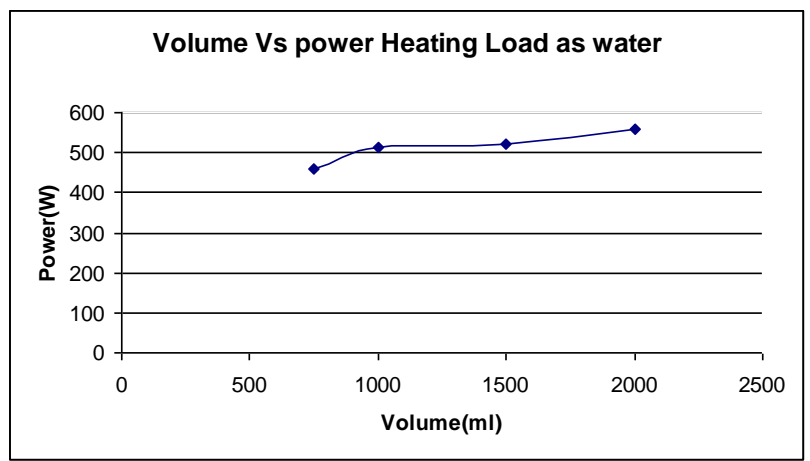

Fig.5 Power Vs Volume plot characteristics with water as heating load.

As the volume increaes the power absorption capability of the medium also increaese. The plot of the power vs volume is having a postive slope.

\section{E. Comparison of various heating loads.}

Table 18 shows the comparison of average values of power absorbed by various heating loads in different time.

Table 18. Final average chart for power analysis with various load and time.

\begin{tabular}{|l|l|l|l|}
\hline Time & $\begin{array}{l}\text { Power in } \\
\text { watts for } \\
\text { water } \\
\text { seconds }\end{array}$ & $\begin{array}{l}\text { Power in watts } \\
\text { for coconut oil }\end{array}$ & $\begin{array}{l}\text { Power in watts } \\
\text { for engine oil }\end{array}$ \\
\hline 60 & 216.205 & 196.827 & 23.459 \\
\hline 120 & 301.36 & 263.479 & 48.847 \\
\hline 180 & 360.322 & 303.814 & 79.616 \\
\hline
\end{tabular}

Fig.6 shows the power analysis graph for time Vs average absorbed Power for various heating loads such as water, coconut oil, and engine oil.

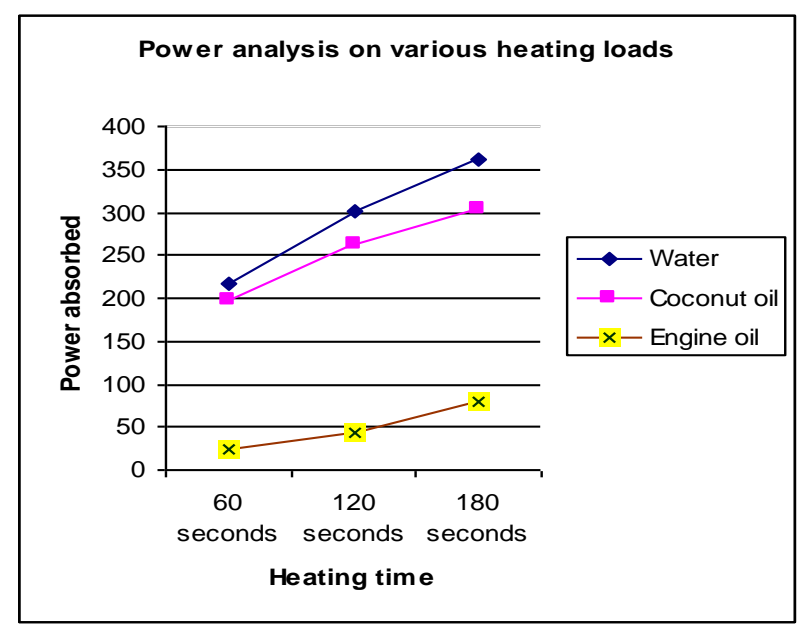

Fig.6 Time Vs average absorbed power for various heating loads

\section{CONCLUSION}

Various heating loads like water, coconut oil, engine oil and, fruit juice were analyzed for power consumption. It was found that absorbed power varies with type of heating load. 
Among the two oils, Coconut oil exhibited 50\% increase and engine oil $300 \%$ increase in absorbed power as time of exposure to microwave was increased from 60 to 180 seconds. Power absorption of coconut oil goes to a steady value as time elapses, whereas engine oil does not exhibit this saturation tendency within the time frame of the experiment. Engine oil maintains a linear power - temperature relationship. On the other hand the overall power absorption by engine oil is very much less compared to an equal mass of coconut oil. These points are particularly interesting especially in the scenario of recent efforts to develop eco friendly engine oils using vegetable oils. In this experiment it was observed that water load exhibits largest absorption. This is due to the fact that microwave energy corresponding to the frequency $2.45 \mathrm{GHz}$ is absorbed very well by polar water molecules which results in efficient dielectric heating than many other molecules. Power absorption by water more or less saturates above a volume of $1 \mathrm{~L}$. This implies that minimum 1L volume of water load is required for efficient energy transfer between the microwave source and load. An important observation made in the case of fruit juice is that as the concentration increases the power absorption increases. This is due to the reason that when the solution concentration changes, the dielectric property changes which in turn changes the power absorption. Another reason for this can be that as the solute concentration increases the quantity of heat transferred between water molecules and solute molecules increases which in turn increases the power absorption.

\section{REFERENCES}

[1] Alexander Irzh, Isaschar Genish, "Synthesis of $\mathrm{ZnO}$ and $\mathrm{Zn}$ nano particles in microwave plsma and their deposition on glass slides", Langmuir 2010,26(8),5976-5984
[2] Jirina Housova and Karel Hoke, "Microwave Heating - the Influence of Oven and Load Parameters on the Power Absorbed in the Heated Load", Food Research Institute, Journal of food science, volume 20, No3: Page 117-124.

[3] Leo Mendel D Rosario and Roy B. Tumlos "Calorimetric Measurements of the Output Power of the $2.48 \mathrm{GHz}$ Commercial Magnetron", Plasma Physics Laboratory, science Dilman July-December 2004.

[4] Ricardo malheiro, "microwave heating: a time saving technology or a way to induce vegitable oils oxidations",material science and engineering, INTech February 2011, pp 597-611.

[5] G.Ajithkumar," Analysis, modification and evaluation of the cold flow properties of vegetable oils as base oils for industrial lubricants", Thesis, July 2009.

[6] Gerhard knoth, "Historical perspectives on vegetable oil based diesel fuels", Volume 12, November 2001, pp1103.

[7] Klamman and Dieter, "Lubricants and Related Products", Verlag Chemie, 1984, ISBN 0-89573-177-0.

[8] Muhammad shanawas and Saghir Ahmed sheikh , “ Analysis of viscosity of jamun fruit juice, squash and jam at different compositions to ensure the suitability of processing applications", International journal of plant physiology and bio chemistry, Volume 3(5), pp 89-94 May 2011.

[9] David J Brookes and Richard E Douthwaitea, "Microwaveinduced plasma reactor based on a domestic microwave oven for bulk solid state chemistry"-Dalton transactionissue 10-2007. 